\title{
EFFECT OF CANCER RELATED FATIGUE TO THE LEVEL OF INDEPENDENCE OF CANCER PATIENTS AND CAREGIVER STRESS LEVEL
}

\author{
Yesiana Dwi Wahyu Werdani \\ Faculty of Nursing, Catholic University Widya Mandala Surabaya, Indonesia
}

\begin{abstract}
ABSTRAK
Kemoterapi/radiasi pada pasien kanker menyebabkan timbulnya cancer-related fatigue (CRF) yang mempengaruhi tingkat kemandirian activity of daily living (ADL) pasien, sehingga tanggung jawab caregiver selama perawatan pasien semakin berat. Hal ini berdampak terhadap timbulnya stres caregiver. Tujuan penelitian membuktikan pengaruh CRF terhadap tingkat kemandirian pasien kanker dan tingkat stres caregiver. Penelitian ini adalah penelitian analitik asosiatif. Populasi pada penelitian ini adalah pasien kanker dan caregiver di Yayasan Kanker Indonesia Cabang Jawa Timur. Jumlah sampel 30 pasien kanker dan 30 caregiver, diambil melalui metode total sampling. Penilaian berdasarkan instrumen brief fatigue questionnaire, activity of daily living berdasarkan Katz, dan caregiver stress self asssessment questionnaire. Pengaruh tingkat CRF terhadap tingkat kemandirian $p=0.000$, tingkat kemandirian terhadap tingkat stres caregiver $p=0.000$. Sebagai simpulan, kegagalan fungsi otot akibat CRF menurunkan kemandirian ADL pasien, sehingga caregiver harus meluangkan banyak waktu pribadi untuk merawat pasien, hal ini berdampak terhadap peningkatan stres caregiver. (FMI 2018;54:108-112)
\end{abstract}

Kata kunci: Cancer-related fatigue; tingkat kemandirian; caregiver

\begin{abstract}
Chemotherapy/radiation in cancer patients causes cancer-related fatigue (CRF). It affects the level of independence of patients' activity of daily living $(A D L)$. Thus, the responsibility of caregivers will be higher and it impacts on caregiver stress level. The aim of this study was to prove the effects of CRF on independence level of cancer patients and caregivers' stress level. This study used analytical associative design. The population was cancer patients and caregivers in Yayasan Kanker Indonesia in East Java. The number of samples were 30 cancer patients and 30 caregivers, taken by total sampling method. The assessment was based on instrument brief fatigue questionnaire, activity of daily living based on Katz, and caregiver stress on self assessment questionnaire. The effects of CRF on the level of independence were indicated by $p=0.000$, and the levels of independence of the caregiver stress level were indicated by $p=0.000$. As a conclusion, the failure of muscle function due to CRF can affect the independence of patient's ADL fulfilling, so caregiver should take much time to treat patient and it affects on the increased stress level of caregiver. (FMI 2018;54:108-112)
\end{abstract}

Keywords: Cancer-related fatigue; level of independence; caregiver

Correspondence: Yesiana Dwi Wahyu Werdani, Jl. Raya Kalisari Selatan 1 Pakuwon City, Surabaya, Indonesia. Phone: 0858-5796-7430. Email: ywerdani@yahoo.com

\section{INTRODUCTION}

Cancer is a continuous, uncontrolled, unlimited, abnormal cell growth which damages tissues and spreads to other organs quickly (Mardiana 2007). Treatment for cancer patients includes surgery, chemotherapy and radiation. The immediate effect of such therapy is the destruction of the entire organ system, the disruption of organ system activity regulation, resulting in a drastic decrease in various body functions of physical and mental fatigue, which is often called cancer-related fatigue (CRF) (Ryan et al 2007).

These disorders cause decreased somatomotor drive, neurotransmission of the central nervous system, endocrine changes, disruption of regeneration of adenosine triphosphate (ATP) skeletal muscle, so that patients feel various complaints, such as fatigue, anorexia, nausea, and vomiting (Ryan et al 2007). CRF is not only physical, but also psychological. According to Ronnback and Hannson (2004), fatigue in cancer patients includes psychological fatigue and stress. Werdani (2017) explains that $90.6 \%$ of cancer patients experience severe stress. This is one of psychological CRF. The main impact of the CRF is the disruption of the function of daily needs fulfillment. Reduced selfsufficiency of ADL patients results in increased patients' independence on the caregivers. Diaz et al (2008) states the impact of CRF causes $58.3 \%$ of patients experience limitations in performing self-care (bathing, dressing, undressing). 
The low level of patient independence and duration of care provide primary stressors to the caregiver, which may lead to the emergence of mental stress on the caregiver (Tantono et al 2009). According to the results of the preliminary survey in August 2016, so far the symptoms of CRF, the degree of autonomy of cancer patients and the level of caregiver stress in the Yayasan Kanker Indonesia (YKI, Indonesian Cancer Foundation) of East Java branch had not been studied. The purpose of this study was to prove the effect of CRF on the level of independence of cancer patients and the influence of independence level on caregivers' stress level.

\section{MATERIALS AND METHODS}

This study used associative research design. The samples were 30 cancer patients and 30 caregivers in YKI Branch East Java. Samples were taken by total sampling method. Three types of instruments were used: brief fatigue questionnaire, activity of daily living based on Katz, and caregivers' stress self-assessment questionnaire. After the respondent signed the informed consent, the patient was given a questionnaire on brief fatigue, an activity of daily living questionnaire based on Katz, while the caregivers were given self-assessment questionnaire about their stress. After the data were collected, we performed coding, scoring, tabulation, and linear regression statistical test.

\section{RESULTS}

Table 1. General data on the patients at Indonesian Cancer Foundation of East Java Branch, March 2017

\begin{tabular}{|c|c|c|c|}
\hline General data & Categories & Frequency & Percentage $(\%)$ \\
\hline \multirow[t]{5}{*}{ Age } & $\leq 30$ y.o & 3 & 10 \\
\hline & $\overline{3} 1-40$ у.о & 4 & 13.3 \\
\hline & $41-50$ y.o & 12 & 40 \\
\hline & $51-60$ y.o & 9 & 30 \\
\hline & $>60$ y.o & 2 & 6.7 \\
\hline \multirow[t]{2}{*}{ Sex } & Female & 22 & 73.3 \\
\hline & Male & 8 & 26.7 \\
\hline \multirow{8}{*}{$\begin{array}{l}\text { Cancer }(\mathrm{Ca}) \\
\text { type }\end{array}$} & Mammary & 9 & 30 \\
\hline & Cervical & 6 & 20 \\
\hline & Nasopharyngeal & 8 & 26.7 \\
\hline & Intestinal & 2 & 6.7 \\
\hline & Ovarian & 2 & 6.7 \\
\hline & Pulmonary & 1 & 3.3 \\
\hline & Lymph & 1 & 3.3 \\
\hline & Rectal & 1 & 3.3 \\
\hline \multirow{4}{*}{$\begin{array}{l}\text { Stages of } \\
\text { cancer }\end{array}$} & I & 1 & 3.3 \\
\hline & II & 8 & 26.7 \\
\hline & III & 13 & 43.3 \\
\hline & IV & 8 & 26.7 \\
\hline \multirow{4}{*}{$\begin{array}{l}\text { Cancer- } \\
\text { diagnosed } \\
\text { period }\end{array}$} & $<1$ year & 11 & 36.7 \\
\hline & $1-<2$ years & 12 & 40 \\
\hline & $2-<3$ years & 2 & 6.7 \\
\hline & $\geq 3$ years & 5 & 16.6 \\
\hline
\end{tabular}

Table 2. General data on caregivers at Indonesian Cancer Foundation of East Java Branch, March 2017

\begin{tabular}{llcc}
\hline General data & Categories & Frequency & $\begin{array}{c}\text { Percentage } \\
(\%)\end{array}$ \\
\hline Age & $\leq 30$ y.o & 6 & 20 \\
& $31-40$ y.o & 6 & 20 \\
& $41-50$ y.o & 10 & 33.3 \\
& $51-60$ y.o & 6 & 20 \\
& $>60$ y.o & 2 & 6.7 \\
\hline Work leaving & Yes & 24 & 80 \\
status & No & 6 & 20 \\
\hline Duration of & $\leq 6$ months & 12 & 40 \\
work leaving & $7-12$ months & 5 & 16.7 \\
& $>12$ months & 7 & 23.3 \\
& Still working & 6 & 20 \\
\hline Duration of & $<1$ year & 15 & 50 \\
patient & $1-<2$ years & 13 & 43.3 \\
caregiving & $2-3$ years & 2 & 6.7 \\
\hline Time of & $1-2$ h/day & 7 & 23.3 \\
caregiving in a & $3-4$ h/day & 5 & 16.7 \\
day & $5-6$ h/day & 2 & 6.7 \\
& $>6$ h/day & 16 & 53.3 \\
\hline Relation with & Core family & 26 & 86.7 \\
the patients & Non-core & 4 & 13.3 \\
& family & & \\
\hline
\end{tabular}

Table 3. Level of Cancer Related Fatigue (CRF) in patients at Cancer Foundation Indonesia East Java Branch, March 2017

\begin{tabular}{lcc}
\hline \multicolumn{1}{c}{ CRF levels } & Frequency $(\mathrm{n})$ & Percentage $(\%)$ \\
\hline Mild & 2 & 6.7 \\
Moderate & 13 & 43.3 \\
Severe & 15 & 50 \\
\hline
\end{tabular}

Table 4. Patient self-reliance rate at Indonesian Cancer Foundation of East Java Branch, March 2017

\begin{tabular}{lcc}
\hline \multicolumn{1}{c}{\begin{tabular}{c} 
ADL independence \\
\multicolumn{1}{c}{ levels }
\end{tabular}} & Frequency & Percentage (\%) \\
\hline Totally independent & 4 & 13.3 \\
Most mildly dependent & 4 & 13.3 \\
Mildly dependent & 4 & 13.3 \\
Moderately dependent & 3 & 10 \\
Highly dependent & 11 & 36.8 \\
Most highly dependent & 0 & 0 \\
Totally dependent & 4 & 13.3 \\
\hline
\end{tabular}

\section{DISCUSSION}

\section{Cancer-related fatigue}

Studies have shown that most of the patients had severe fatigue. Severe fatigue is defined as the fatigue felt by the patients for the last 24 hours that disrupts their 
activity, worsens their mood, and prevents interaction with others, so the enjoyment of life is interrupted. Kummer et al (2013) mentioned that $49.14 \%$ of cancer patients suffered from severe fatigue. CRF is developed from cancer therapy, in which most patients undergo more than one type of therapy.

Kummer et al (2013) mentioned that $63.89 \%$ fatigue prevalence of cancer patients occurs significantly when they enter the therapy/rehabilitation stage. Wang (2012) explained that chemotherapy, surgery and radiation affect the stimulation of proinflamatory cytokines. This causes changes in circadian rhythms, growth hormone, HPA-Axis dysfunction, depression, cachexia, serotonin disorders, vagal-afferent nerve activation, anemia and ATP function. These lead to the emergence of CRF.

\section{Independence levels}

Based on the results of the study, most patients experienced severe depression. The patients were unable to carry out self-activities, such as taking a bath, dressing, toileting, and ambulatory moving as well as mobility, which should be assisted by the caregiver. This was because the emergence of fatigue which directly gave effect to the physiological disorders in the activity to meet the basic needs. Mohile et al (2009) explained that chemotherapy and radiation can cause muscle strength decrease in cancer patients, which can lead to weakness and impact on the high level of dependence on fullfilling their daily activity. Hansen et al (2015) also found the same results of 118 respondents with cancer.

As many as $65 \%$ reported a change in meeting the needs of ADL with high degree of difficulty. The decreased level of patient independence was also influenced indirectly by the psychological condition of psychological stress. Werdani (2017) mentioned that $90.6 \%$ of cancer patients experienced severe stress. Severe stress caused a person unable to control himself, which greatly affected his ability to move (Werdani 2017).

Table 5. Caregiver stress level at Indonesia Cancer Foundation of East Java Branch, March 2017

\begin{tabular}{lcc}
\hline \multicolumn{1}{c}{ Stress levels } & Frequency & Percentage (\%) \\
\hline Mild & 13 & 43.4 \\
Moderate & 16 & 53.3 \\
Severe & 1 & 3.3 \\
\hline
\end{tabular}

\section{Caregiver stress level}

In this study, caregivers mostly experienced stress at moderate level. Caregiver felt that sometimes the patients asked for help more than they actually needed and they treated the caregiver as the only one they depended on.

Table 6. Cross tabulation CRF level and Patient Self-Reliance Rate at Indonesia Cancer Foundation East Java Branch, March 2017

\begin{tabular}{lccc}
\hline \multirow{2}{*}{ Independence levels } & \multicolumn{3}{c}{ CRF levels } \\
\cline { 2 - 4 } & Mild & Moderate & Severe \\
\hline Totally independent & 1 & 3 & 0 \\
Most mildly dependent & 1 & 3 & 0 \\
Mildly dependent & 0 & 4 & 0 \\
Moderately dependent & 0 & 2 & 1 \\
Highly dependent & 0 & 1 & 10 \\
Most highly dependent & 0 & 0 & 0 \\
Totally dependent & 0 & 0 & 4 \\
\hline
\end{tabular}

Table 7. Cross tabulation of patient independence and Caregiver Stress at the Indonesian Cancer Foundation of East Java Branch, March 2017

\begin{tabular}{lccc}
\hline \multirow{2}{*}{ Independence levels } & \multicolumn{3}{c}{ Stress levels } \\
\cline { 2 - 4 } & Mild & Moderate & Severe \\
\hline Totally independent & 4 & 0 & 0 \\
Most mildly dependent & 4 & 0 & 0 \\
Mildly dependent & 3 & 1 & 0 \\
Moderately dependent & 1 & 2 & 0 \\
Highly dependent & 1 & 9 & 1 \\
Most highly dependent & 0 & 0 & 0 \\
Totally dependent & 0 & 4 & 0 \\
\hline
\end{tabular}

The caregivers felt that they no longer had enough time for themselves. Sometimes there was dilemma between personal needs and caring responsibilities. The caregivers also felt that their health had been disrupted due to prolonged patient care and spent quite a bit of money. This was probably because most caregivers (50\%) had been accompanying the patient for $<1$ year of illness and also has treated patients $>6$ hours a day $(53.3 \%)$. Girgis et al (2013) conducted a literature review about caregiver. He explained that caregivers who provided care to patients with chronic illness for several years were equivalent to regular employment, which can result in significant health, psychosocial, and financial burdens. Provision of routine care in patients with chronic disease, conducted over a long period of time with a duration of treatment $>6$ hours per day will cause boredom and distress. This was because the lack of time that caregiver obtained to care for himself, so it can cause increased physical and psychological load of the caregiver or often referred to as caregiver burden. It was the mental pressure that appeared in people who care for the elderly or patients with chronic diseases or disabilities (Tantono et al 2006). Longacre (2014) also found similar finding, that of 104 caregivers in cancer patients, mostly experienced an increase in emotional stress. Mahadevan et al (2013) also stated that of the 
130 families who became caregiver in cancer patients, $24.6 \%$ experienced stress and depression.

\section{Influence of CRF against independence level of cancer patients}

Based on the linear regression test, $\mathrm{p}$ value $=0.000$ was obtained, indicating there was a significant influence between the CRF level with the level of independence of cancer patients. The value of $r$ obtained was 0.82 , suggesting that the CRF level gives an effect of $80.2 \%$ on the level of patient independence.

This occurred because of the effects of various therapies on cancer patients, which massively lead to reduced ATP and accumulation of metabolic products. This results in peripheral neuromuscular inability in response to central stimulation, resulting in progressive motor impulses failure. Failure in muscle use due to CRF affects the patient's ability to meet the needs of daily activities (Ryan et al 2007). Hewitt et al (2003) explained that $30 \%$ of adults who suffer from cancer reported poor fatigue and have limited ability to perform activities of daily living.

\section{Effect of independence level of cancer patients on caregiver stress level}

Based on linear regression test results, we obtained $\mathrm{p}$ value $=0.000$, indicating that there was significant influence of independence levels on cancer patients with stress levels of caregivers. The value of $r$ obtained was 0.734 , which means the decrease in the independence level of cancer patients had an effect of $73.4 \%$ against the caregiver stress level. This was likely due to the impact of CRF which caused a decrease in muscle capacity in contraction to perform daily activities, so that all patients' needs could not be done independently, but required the help of others. The dependence on others in ADL compliance caused caregivers to spend a lot of personal time to take care of patients, thus triggering stress on the caregivers.

Psychological stress leads to HPA-Axis stimulation which can cause various physical complaints to the caregiver. Sternberg (2006) explained that all stressors can activate the HPA axis and the adrenergic sympathetic nervous system. After exposure to stress, the hypothalamus releases a corticotropin releasing hormone that stimulates the pituitary gland to release the adrenocorticotropic hormone (ACTH). ACTH further triggers the release of glucocorticoids (cortisol) from the adrenal cortex. At the same time, the sympathetic nervous system is activated by adrenaline release from the adrenal medulla and norepinephrine of the sympathetic nerves. Molecules released during a stress response have an effect on the function of most cells and organs throughout the body, including the brain, heart, respiratory system, muscles, skin, liver, gastrointestinal tract and the immune system.

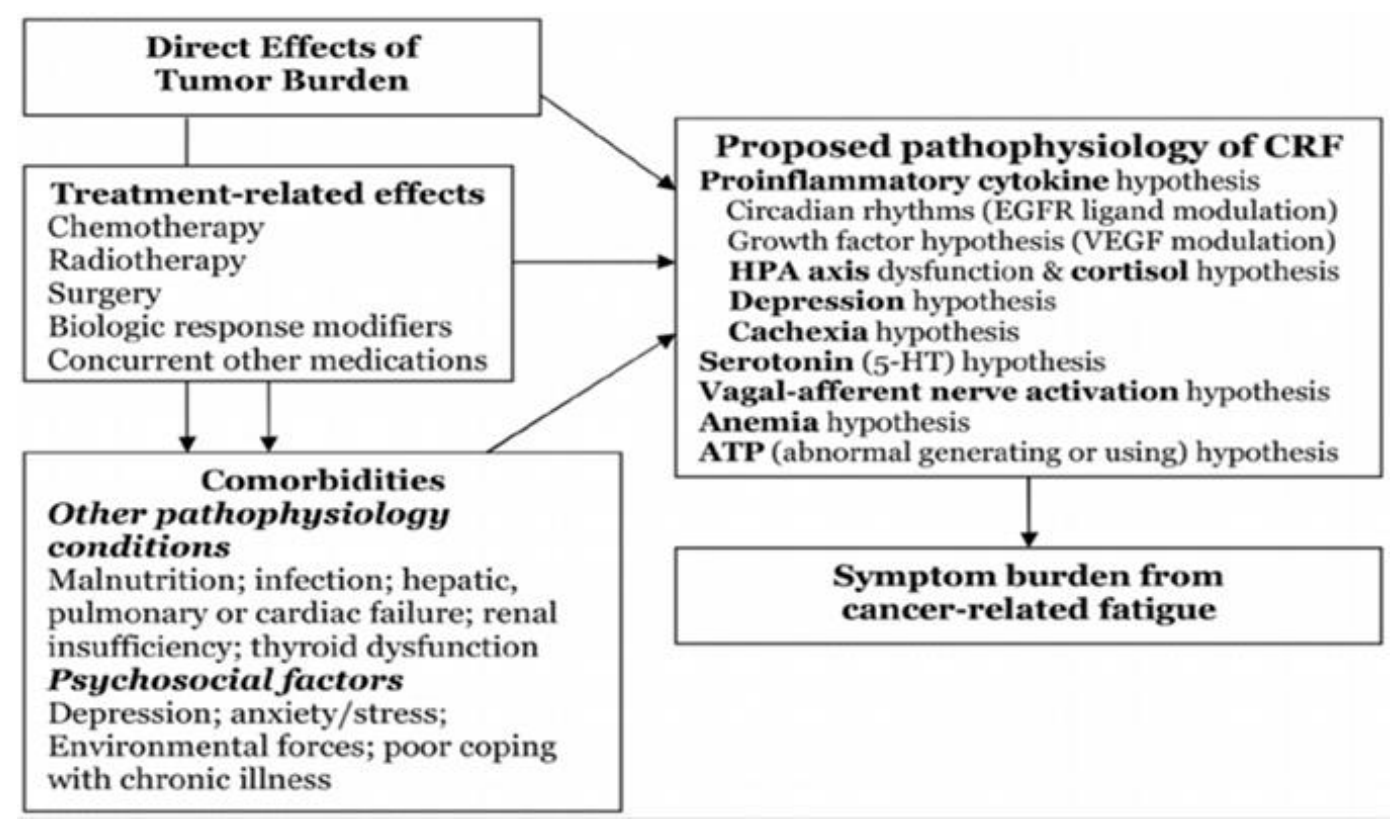

Fig. 1. Pathophysiology of Cancer Related Fatigue (Wang 2012). 


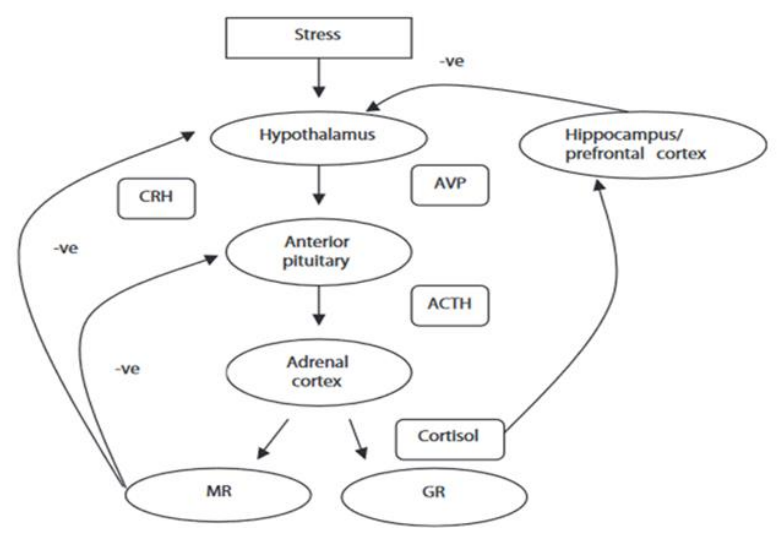

Fig. 2. Stimulation of HPA-Axis (Phillips et al 2006).

\section{CONCLUSION}

Chemotherapy, radiotherapy and surgery can alter the function of HPA-Axis with the onset of endocrine changes that contribute to the onset of cancer related fatigue (CRF). Furthermore, this affects motor muscle contraction and decreases the level of independence in meeting the activity of daily living. The complexity of the CRF and the high level of dependence experienced by the patients leads to an increase in the level of stress of the caregivers who have to provide daily care over a long period of time. This indicates that physiological response of HPA-Axis to stress affects the caregivers' health.

\section{REFERENCES}

Diaz N, Menjon S, Rolfo C, et al (2008). Patients' Perception of Cancer-Related Fatigue: Results of a survey to assess the impact on their everyday life. Clinical and Translational Oncology 10, 753-7

Girgis A, Lambert S, Johnson C, et al (2013). Physical, psychosocial, relationship, and economic burden of caring for people with cancer: A review. Journal of Oncology Practice 9, 197-202

Hansen D, Waehrens E, Cour K, et al (2015). Performance of activities of daily living among hospitalized cancer patients. Scandinavian Journal of Occupational Therapy 22

Hewitt M, Rowland J, Yancik R (2003). Cancer survivors in The United States: Age, health, and disability. Journal of Gerontology 58, 82-91

Kummer F, Catuogno S, Perseus J, et al (2013). Relationship between cancer-related fatigue and physical activity in inpatient cancer rehabilitation. Anticancer Research 33, 3415-3422

Longacre M, Ross E, Fang C (2014). Caregiving choice and emotional stress among cancer caregivers. Western Journal of Nursing Research 36, 806-824
Mahadevan R, Jaafar N, Din S, et al (2013). The stress of caregiving: A study of family caregivers of breast cancer patients receiving oncologic treatment at a Malaysian General Hospital. Sains Malaysiana 42, 1019-1026

Mardiana L (2007). Kanker pada wanita: Pencegahan dan pengobatan dengan tanaman obat. Jakarta, Penebar Swadaya

Mohile S, Xian Y, Dale W, et al (2009). Association of a cancer diagnosis with vulnerability and frailty in older medicare beneficiaries. Journal of the National Cancer Institute 101

Phillips L, McGorry P, Garner B, et al (2006). Stress, the hippocampus and the hypothalamic-pituitaryadrenal axis: implications for the development of psychotic disorders. Australian and New Zealand Journal of Psychiatry 40, 725-741

Ryan J, Carroll J, Ryan E, Mustian K (2007). Mechanism of cancer-related fatigue. The Oncologist 12, 2234

Ronnback L, Hansson E (2004). On The potential of glutamate transport in mental fatigue. Journal of Neuroinflammation 1

Sternberg E (2006). Neural regulation of innate immunity: A coordinated nonspecific host response to pathogens. Nature Review Immunology Journal 6, 318-328.

Tantono H, Siregar I, Hazza Z (2006). Beban caregiver lanjut usia. suatu survey terhadap caregiver lanjut usia di beberapa tempat sekitar Bandung. Bandung, Majalah Psikiatri XL, p 32-33

Wang X (2012). Pathophysiology of cancer-related fatigue. Clinic Journal Oncology Nursing 12, 11-20

Werdani Y (2017). Effect of mindfullness meditation on stress level and coping mechanism in cancer patients. Folia Medica Indonesiana 53, 33-40 